\title{
Over the Century, 1918-2018, Masterpieces of Tapestry
}

\author{
Florian Knothe* \\ The University of Hong Kong, Hong Kong
}

*Corresponding author: Florian Knothe, Director, University Museum \& Art Gallery, University of Hong Kong, Hong Kong.

Received Date: May 28, 2019

Published Date: June 03, 2019

\section{Opinion}

From April 10th through November 4th, 2018, the Mobilier national in Paris celebrated the last 100 years of French tapestry weaving in an exhibition that included the finest textiles after some of the very best known 20th-century artists. "Au fil du siècle, 1918 2018, Masterpieces of the tapestry "highlighted an illustrious group of artworks at the Manufactures of Gobelins, Beauvais, Savonnerie and Aubusson after the designs by Anquetin, Denis, Serriere, Beaume, Cappiello, Bracquemond, Lurcat, Gromaire, Matisse, Picasso, Miró, Le Corbusier, Delaunay, Dufy, Derain, Hartung, Zao Wou-Ki, Vasarely, Morellet, and Bourgeois.

This beautiful and unprecedented exhibition did not only testify to the diversity of subjects modern and contemporary artists, of French and foreign origin, see into production, but also documented the very process of doing so by displaying both tapestries and carpets, as well as some of the cartoons they are based on. The artists' hand and teamwork in the production process has long impressed and it still as strong as during the artform's golden age, when the vitality and quality of the image was cherished, and the excellence of the tight weaving and innovation of the dyeing techniques became world famous. Today, like during the ancient régime, masterpieces from the best (formerly royal) manufactories embellish the fine interior (and exhibition space).

This juxtaposition and the beautiful display at the Gobelins Gallery are noteworthy. In the past, the tapestry workshops at the Gobelins were not compared to other, smaller French weaving shops, such as the Beauvais or the ateliers provincials at Amiens and Tours, or even foreign manufactories. Only the texts concerned with the history of tapestry weaving mention some of the other workshops but, unless one was developed from another, the ateliers were typically described separately, and no valuation or critique was offered for many of the domestic or foreign shops. This lack of information-unacceptable particularly as the Gobelins was relying on foreign expertise throughout its varied production-has been addressed in recent years by publications, including Beauvais, National Manufactory of Tapestry (National Center for Plastic Arts, 1992), Aubusson, Tapestries of the Enlightenment. Splendors of the Royal Manufacture, supplier of Europe in the eighteenth century [1] and The Manufacture of furniture of the crown to the Gobelins under Louis XIV: a Social, Political and Cultural History [2] , such "Baroque Tapestry" at The Metropolitan Museum of Art and "Woven Gold" at the JP Getty Museum [3] and their model catalogs, to which the recent "Over the Century" adds a meaningful modern counterpart testifying to the ongoing strength of this noble artform.

During the golden age, the crown collected art, as Louis XIV inherited and purchased whole collections from re-known collectors, such as Mazarin and Jabach. The royal manufactories produced tapestries locally and added to the often-foreign weavings in the garde meuble. At the time, Charles Le Brun, as director of the Gobelins, was obliged to supply the Bâtiments du roi, by which all the manufactory's artisans were employed, and a public appearance of the workshops' artefacts led to the renown and success of 17th-century French tapestries. Then, the widespread of Gobelins products as well as the universal knowledge of the royal manufactory was generated by the crown and constituted an important asset both for royal court as recipient and the individual ateliers as originators. This development reached its pinnacle under Colbert in the 1660s, when the superintendent of buildings initiated royal manufactories throughout the country, like the tapestry manufactories described here and textile workshops throughout the country, as also those for the production of lace that were begun by Italian workers in Puy, Aurillac, Alençon, Bourges and Auxerre in 1665. Today, the recent exhibition shows just as clearly how, despite the changing times, political regimes, 
as well as societal developments and tastes, French tapestry and carpet making dominates the field, and presents us with such stunning examples as the ones included in the Mobilier national's comprehensive exhibition.

\section{Acknowledgement}

None.

\section{Conflict of Interest}

No conflict of interest.

\section{References}

1. (1886) Histoire de la tapisserie, depuis le moyen age jusqu'à nos jours, Tours, chapter 6, pp. 265-335.

2. (1881) Histoire de la tapisserie en France, Paris 1878-1885 ; Eugène Müntz, La Tapisserie, Paris, Henry Havard, Les arts de l'ameublement : la tapisserie, Paris 1890.

3. (1906) Brisson spoke of more than 8000 workers at Alençon and mentioned 'les Italien' in Aurillac. pp. 152-153. 